\title{
The Effect of Melatonin on Some Coagulation Parameters in Streptozotocin-induced Diabetic Rats
}

\author{
Ercan KESKIN ${ }^{1}$, Deniz ULUIŞIK ${ }^{*}$ \\ ${ }^{1}$ Department of Physiology, Faculty of Veterinary Medicine, University of Selcuk, Konya, Turkey
}

\begin{abstract}
The aim of this study is to evaluate the possible protective effects of melatonin on hemostatic parameters in diabetic rats. For this purpose, 32 adult, male, healthy Wistar Abino rats were seperated into four groups. Control group didn't exposure any trial. Melatonin group was treated with $50 \mathrm{mg} / \mathrm{kg}$ melatonin by intraperitoneally during 8 weeks. In diabetes group, diabetes was induced by subcutaneous injections of streptozotocin at dose of 40 $\mathrm{mg} / \mathrm{kg}$ for two days as a single daily dose. Diabetes+Melatonin group was consist of the animals that treated with $50 \mathrm{mg} / \mathrm{kg}$ melatonin by intraperitoneally to streptozotocin induced diabetic during 8 weeks. In diabetic rats, the platelet count and fibrinogen level significantly increased compared to control group $(p<0.05)$, whereas melatonin application to the diabetic rats caused to decrease in fibrinogen level when compared to diabetic rats $(\mathrm{p}<0.05)$. Activated Partial Tromboplastin Time (APTT), Prothrombin Time (PT) and International Normalized Ratio (INR) levels significantly shortened in the experimentally diabetes group compared to the control group $(\mathrm{p}<0.05)$. PT and INR significantly prolonged in diabetic rats with the melatonin treatment compared to diabetic rats $(p<0.05)$. In conclusion, the obtained data indicated that administration of melatonin partly ameliorated procoagulant state caused by diabetes in rats.
\end{abstract}

Keywords: APT'T, fibrinogen, diabetes, melatonin, rat

\section{Streptozotosin ile Diyabet Oluşturulan Ratlarda Melatonin Uygulamasının Bazı Koagulasyon Parametreleri Üzerindeki Etkisi}

\section{ÖZ}

Bu çalışmanın amacı streptozotosin ile diyabet oluşturulan ratlarda hemostatik parametreler üzerine melatoninin muhtemel koruyucu etkilerinin belirlenmesidir. Bu amaçla 32 yetişkin erkek sağlıklı Wistar Abino rat dört gruba ayrild1. Kontrol grubuna herhangi bir uygulama yapilmadı. Melatonin grubuna 8 hafta boyunca intraperitoneal olarak $50 \mathrm{mg} / \mathrm{kg}$ melatonin uygulandı. Diyabet grubunda $40 \mathrm{mg} / \mathrm{kg}$ streptozotosinin günlük tek doz olmak üzere iki gün subkutan enjeksiyonuyla diyabet oluşturuldu. Diyabet+Melatonin grubuna streptozotosin uygulanarak diyabet oluşturulduktan sonra 8 hafta boyunca intraperitoneal olarak $50 \mathrm{mg} / \mathrm{kg}$ melatonin enjekte edildi. Diyabetik ratlarda platelet sayısı ve fibrinojen seviyesi kontrol grubuna göre önemli oranda artarken $(\mathrm{p}<0.05)$, diyabetik ratlara melatonin uygulaması diyabet grubuna göre fibrinojen düzeyinde azalmaya neden oldu $(\mathrm{p}<0.05)$. Deneysel diyabet grubundaki APTT, PT ve INR düzeyleri kontrol grubuna göre önemli bir şekilde azaldı $(\mathrm{p}<0.05)$. Diyabetik ratlara intraperitoneal olarak melatonin uygulaması ile PT ve INR düzeyleri diyabetik ratlara göre önemli bir şekilde uzadı $(\mathrm{p}<0.05)$. Sonuç olarak, bu çalışmadan elde edilen veriler melatonin uygulamasının ratlarda diyabetten kaynaklanan prokoagulan durumu kısmen düzelttiğini göstermektedir.

Anahtar Kelimeler: APT'T, fibrinojen, diyabet, melatonin, rat

To cite this article: Ulussı D. Keskin E. The Effect of Melatonin on Some Coagulation Parameters in Streptozotocin-induced Diabetic Rats. Kocatepe Vet J. (2019) 12(2):130-134. 


\section{INTRODUCTION}

In the worldwide, there is an increase in death due to atherothrombotic disorders result from metabolic disorders such as diabetes mellitus (DM), hypertension and obesity (Sanz and Fuster 2011, Korish et al. 2015). Diabetes mellitus caused by either low insulin level or high insulin resistance is characterized with high hyperglycemia and the other metabolic disorders (Yeom et al. 2016). Millions of people are affected by cardiovascular diseases related to diabetes mellitus (Kakouros et al. 2011). In later stages, diabetes mellitus causes abnormal endothelial function, increase of arterial stiffness, platelet hyperreactivity and hemorheological changes (Wilkinson et al. 2000, Schäfer et al. 2007, Cho et al. 2008, Yeom et al. 2016). Another complication of diabetes is hemostatic disorders. Some studies claim that diabetes increases the tendency to coagulation (Takada et al. 1993, Osende et al. 2001, Creager et al. 2003, Ferreiro et al. 2010, Ferreiro and Angiolillo 2011). These serious disturbances play a crucial role in the etiology of diabetes-related vascular complications including arteriosclerosis and myocardial infarction (Beckman et al. 2002, Loomans et al. 2004, Yeom et al. 2016). Thrombotic disorders and vascular lesions such as microvasculopathy, retinopathy and macroangiopathy, especially in the coronary and cerebral vessels can be life threatening. Rupture of an atherosclerotic plaque promotes platelet activation and locally triggering of the coagulation process that can cause thrombus formation at the region of endothelial damage (Kakouros et al. 2011). It has been stated that cardiovascular and cerebrovascular disorders frequently occurred in diabetes due to micro- and macrovascular complications (American Diabetic Association 2011, Eriksson et al. 2012, Korish et al. 2015).

Many therapeutic approaches have been still studied to alleviate the complications of diabetes. Recently, studies have been focused on melatonin as a therapeutic agent due to its several physiological activities (Carrillo-Vico et al. 2005, Claustrat et al. 2005). In 1958, Lerner's group first isolated melatonin (N-acetyl-5-methoxy-tryptamine) from the bovine pineal gland (Minneman and Wurtman 1976). Melatonin production is regulated by the suprachiasmatic nucleus (SCN) as known the central circadian pacemaker (Carrillo-Vico et al. 2005). It is synthesized in several organs, including the pineal gland, Harder's glands, gastroenteric mucous membrane, retina, platelets and megakaryocytes (Reiter et al. 1988). Melatonin has high lipid and water solubility features, thus it passes easily across cell membranes (Claustrat et al. 2005). Pineal secretion reaches maximum plasma levels around 03:00-04:00 a.m. During the day, its level is low or even undetectable (Follenius et al. 1995, Rodella et al. 2013).

Although, there is a limited data about the effects of melatonin on coagulation, there are various findings about the effect of melatonin on cardiovascular incidents, hemorrhage, activities of some coagulation proteins and fibrinolytic systems regarding in subjected to circadian variations (Pinotti et al. 2005, Montagnana et al. 2009). Some studies reported that melatonin may used for hemostasis bu using in a different route, doses and period to animals and human (Tunali et al. 2005, Tai et al. 2010, Kostovski et al. 2011). It was also suggested that there is a dosedependent relationship between plasma melatonin level and coagulation activity (Wirtz et al. 2008, Pashalieva et al. 2014).

Based upon these acknowledgements we aimed to determine the effects of melatonin on some coagulation parameters in streptozotocin-induced diabetic rats.

\section{MATERIALS and METHODS}

In the study, 32 male, 6 weeks of age, healthy Wistar Abino rats were used. The animals were divided into four groups. All animals were fed with standart rat diet as ad libitum during 8 weeks. The Ethical Committee of Selcuk University Experimental Medicine Research and Application Center approved the study protocol (Report no. 2017-15).

- The animals in control group $(\mathrm{n}=6)$ didn't exposure any treatment.

- Melatonin group ( $\mathrm{n}=6$ ) was injected with $50 \mathrm{mg} / \mathrm{kg}$ melatonin (Sigma-Aldrich, St. Louis, MO, USA) intraperitoneally during 8 weeks.

- Diabetes group $(\mathrm{n}=10)$ was induced by subcutaneously injected with streptozotocin (SigmaAldrich, St. Louis, MO, USA) at dose of $40 \mathrm{mg} / \mathrm{kg}$ in $0.1 \mathrm{M}$ citrate buffer ( $\mathrm{pH}$ 4.5) for two days as a single daily dose.

- Diabetes+Melatonin group $(\mathrm{n}=10)$ was injected with $50 \mathrm{mg} / \mathrm{kg}$ melatonin intraperitoneally to the diabetic rats during 8 weeks.

In the cases of streptozotocin-induced hypoglycemia, rats were given $5 \%$ dextrose solution as a precaution after $6 \mathrm{~h}$ of streptozotocin administration during next 3 days. Diabetes was verified by measuring blood glucose level strips using glucometer (PlusMED Accuro, Taiwan) via the tail vein after one week from streptozotocin injections. Animals, which have a blood glucose level higher than $250 \mathrm{mg} / \mathrm{dl}$, were accepted as diabetic and were included in the experiment. During the experiment, one animal from diabetes group were died due to streptozotocininduced hypoglycemia. 
At the end of the 8 weeks, blood samples were taken from all animals. In these blood samples, platelet, fibrinogen, activated partial thromboplastin time (APTT), prothrombin time (PT), international normalized ratio (INR) levels were determined. Platelet, fibrinogen, APTT, PT, INR levels were determined by using Abbott kits in Abbott analyzer (Abbott Architect i2000).

The data obtained from the study were analyzed by one-way ANOVA (SPSS 19). Differences among the groups were determined by Duncan's multiple range test. Differences were considered significant at $\mathrm{p}<0.05$.

\section{RESULTS}

The effect of melatonin on coagulation parameters in experimentally induced diabetes in rats were summarized Table 1. In diabetic rats, the platelet count and fibrinogen level significantly increased compared to control group $(\mathrm{p}<0.05$, Table 1$)$, whereas intraperitoneally melatonin application to the diabetic rats caused to decrease in both parameters when compared to diabetic rats. The decrease in fibrinogen level was significant $(p<0.05$, Table 1$)$. In this study, APTT, PT and INR levels in the experimentally diabetes group significantly shortened compared to control group $(\mathrm{p}<0.05$, Table 1$)$. With the intraperitoneally melatonin application to the diabetic rats, PT and INR significantly prolonged compared to diabetic rats $(p<0.05$, Table 1$)$, while the changes in APT'T was not important statistically.

\section{DISCUSSION}

In diabetes mellitus, cardiovascular complications and the other metabolic disorders generally coexist and lead to high morbidity and mortality in worldwide. It is frequently seen that prothrombotic conditions such as platelet hyperreactivity, impaired fibrinolysis, endothelial dysfunction and increased coagulation cause these cardiovascular complications in diabetes. (Takada et al. 1993, Osende et al. 2001, Creager et al. 2003). Some mechanisms caused by metabolic and cellular abnormalities have been accepted as a reason of coagulation tendency in diabetes mellitus. These mechanisms and their ethiologies were been categorized as hyperglycemia, insulin deficiency and resistance associated with metabolic conditions and other cellular abnormalities. (Ferreiro et al. 2010, Ferreiro and Angiolillo 2011). In parallel with the knowledge that mentioned above, coagulation parameters were significantly impaired in streptozosin induced diabetic rats in this study. So that, thrombocyte count and fibrinogen level significantly increased in diabetic group compared to control group ( $\mathrm{p}<0.05$, Table 1$)$, whereas APT'T, PT and INR shortened compared to control group $(\mathrm{p}<0.05$, Table 1). Ohaeri and Adoga (2006) reported that the increases in platelet count and coagulation factors amount (factor V, VII, VIII, IX and X) were determined in experimentally diabetic rats compared to control rats. In addition, plasma fibrinogen levels were found to be higher as parallel to hyperglycemic degree in many studies conducted with diabetes (Ceriello et al. 1994, Schalkwijk et al. 1999, Dunn and Ariëns 2004). In another study, it has been stated that PT, APTT and coagulation time in diabetic rats were found to be lower than control group, while platelet count and plasma fibrinogen levels in diabetic rats were obtained as higher than control group's level (ElGendy and Abbas 2014). It was suggested that hyperglycemia exposure may induce procoagulant state in diabetes due to hemorheological changes of thrombocytes, platelet aggregation, endothelial dysfunction and increasing levels of tissue factors (Yeom et al. 2016). Another pathway of activation of procoagulant state is that hyperglycemia leads to increasing levels of tissue factor, prothrombin fragments, decreasing factor VII/VIIa and increasing factor VIII (Vaidyula et al. 2006b). In addition, it was reported that hyperglycemia upregulate platelet expression of CD40L and increase monocyte-platelet aggregates as indicative of platelet activation (Vaidyula et al. 2006a, Kakouros et al. 2011).

Melatonin, a signaling molecule for circadian rhythms, plays an important role in many biological processes (Dahm et al. 2006, Kostovski et al. 2011). It was suggested that endogenous melatonin may also produce antithrombotic, antioxidant and antiinflammatory activity (Carrillo-Vico et al. 2005, Claustrat et al. 2005, Dahm et al. 2006, Ashy and Shroff 2016). Depend on its wide effects, melatonin could be expected to regulate hemostatic events and the effects of melatonin on hemostasis are relatively poorly studied (Kostovski et al. 2011). For this reason, we determined some hemostatic parameters in diabetic rats treated with melatonin. Melatonin treatment significantly decreased plasma fibrinogen levels compared to diabetic group, while PT and INR levels significantly increased when compared diabetic group $(p<0.05$, Table 1$)$. The changes in platelet count and APTT with the melatonin treatment to diabetic rats were not important statistically. In the light of our results, it might be said that melatonin has favorable effects on hemostatic parameters in streptozotocin-induced diabetic rats. These effects of melatonin on hemostasis such as inhibiting procoagulant state were attributed to some mechanisms. Kostovski et al. (2011) reported that melatonin increased tissue factor pathway inhibitor (TFPI) in endothelial cells in vitro. In contrary, it was suggested that plasma TFPI level is low when plasma melatonin levels peak in darkness, vice versa (Dahm et al. 2006). Protein $C$ anticoagulant pathway is one of important mechanisms of the anticoagulant system. This pathway includes membrane proteins and circulating proteins (such as protein C, thrombomodulin, endothelial protein $\mathrm{C}$ receptor 
(EPCR) and protein S) (Castellino and Ploplis 2009, Stancheva et al. 2015). Castellino and Ploplis (2009) stated that melatonin significantly reduced activity of protein $\mathrm{C}$ anticoagulant pathway in rats. The beneficial effects of melatonin related to procoagulant state might based on endothelium protective effects (Rodella et al. 2013). In diabetes, increased in plasma glucose levels contribute endothelial dysfunction characterized by proliferating barrier function and adhesion of circulating cells (Ho et al. 2000, Ido et al. 2002, Favaro et al. 2008). Therefore, melatonin with its antioxidant and antiinflamatory properties is being expected to act protective on endothelial dysfunction arise from diabetes. Thus, melatonin activates antioxidants such as superoxide dismutase, catalase, glutathione peroxidase, glutathione reductase and glucose-6-phosphate dehydrogenase (Rezzani et al. 2006, Bharti and Srivastava 2009), protects cells from oxidative damage and apoptosis (Jou et al. 2007, Rodella et al. 2013).

Table 1. Effect of melatonin on coagulation parameters in diabetes (Mean \pm SE)

\begin{tabular}{lccccc}
\hline & $\begin{array}{c}\text { Platelet } \\
(\mathrm{K} / \mu \mathrm{l})\end{array}$ & $\begin{array}{c}\text { Fibrinogen } \\
(\mathrm{mg} / \mathrm{dl})\end{array}$ & $\begin{array}{c}\text { APTT } \\
(\mathrm{sec})\end{array}$ & $\begin{array}{c}\text { PT } \\
(\mathrm{sec})\end{array}$ & INR \\
\hline Control & $690.50 \pm 27.65^{\mathrm{b}}$ & $227.83 \pm 22.39^{\mathrm{b}}$ & $35.62 \pm 3.30^{\mathrm{a}}$ & $11.60 \pm 0.211^{\mathrm{ab}}$ & $1.05 \pm 0.02^{\mathrm{a}}$ \\
Melatonin & $711.83 \pm 37.62^{\mathrm{b}}$ & $193.67 \pm 18.79^{\mathrm{b}}$ & $36.78 \pm 3.18^{\mathrm{a}}$ & $11.80 \pm 0.10^{\mathrm{a}}$ & $1.06 \pm 0.01^{\mathrm{a}}$ \\
Diabetes & $827.56 \pm 20.71^{\mathrm{a}}$ & $313.56 \pm 24.37^{\mathrm{a}}$ & $24.21 \pm 2.80^{\mathrm{b}}$ & $9.79 \pm 0.29^{\mathrm{c}}$ & $0.90 \pm 0.02^{\mathrm{b}}$ \\
Diabetes+Melatonin & $747.20 \pm 25.44^{\mathrm{ab}}$ & $248.30 \pm 18.71^{\mathrm{b}}$ & $31.59 \pm 2.14^{\mathrm{ab}}$ & $10.92 \pm 0.24^{\mathrm{b}}$ & $1.00 \pm 0.02^{\mathrm{a}}$ \\
\hline
\end{tabular}

${ }_{\mathrm{a}-\mathrm{c}}$ The difference between mean values with different superscripts in the same column is significant at the $\mathrm{p}<0.05$ level.

\section{CONCLUSIONS}

As a result, the obtained data from this study indicated that administration of melatonin partly improved procoagulant state caused by diabetes in rats. Nevertheless, the further studies are needed established with different melatonin doses related to hemostatic state in diabetes in the future.

\section{ACKNOWLEDGEMENT}

The Ethical Committee of Selcuk University Experimental Medicine Research and Application Center approved the study protocol (Report no. 2017-15).

\section{REFERENCES}

American Diabetic Association. National Diabetes Fact Sheet 2011 (released Jan. 26, 2011). http://www.diabetes.org/diabetes-basics/diabetesstatistics; Last accessed date: 10.09. 2012.

Ashy NI, Shroff KV. Evaluation of the potential drug interaction of melatonin and warfarin: a case series. Life Sci J. 2016; 13(6):46-51.

Beckman JA, Creager MA, Libby P. Diabetes and atherosclerosis: epidemiology, pathophysiology, and management. JAMA. 2002; 287(19):2570-2581.

Bharti VK, Srivastava RS. Pineal proteins upregulate specific antioxidant defense systems in the brain. Oxid Med Cell Longev. 2009; 2(2):88-92.

Carrillo-Vico A, Guerrero JM, Lardone PJ, Reiter RJ. A review of the multiple actions of melatonin on the immune system. Endocrine. 2005; 27(2):189-200.

Castellino FJ, Ploplis VA. The protein C pathway and pathologic processes. J Thromb Haemost. 2009; 7(1):140145.

Ceriello A, Taboga C, Giacomello R, Falleti E, De Stasio G, Motz E, Lizzio S, Gonano F, Bartoli E. Fibrinogen plasma levels as a marker of thrombin activation in diabetes. Diabetes. 1994; 43(3):430-432.

Cho YI, Mooney MP, Cho DJ. Hemorheological disorders in diabetes mellitus. J Diabetes Sci Technol. 2008; 2(6):11301138 .

Claustrat B, Brun J, Chazot G. The basic physiology and pathophysiology of melatonin. Sleep Med Rev. 2005; 9(1):11-24

Creager MA, Lüscher TF, Cosentino F, Beckman JA. Diabetes and vascular disease: pathophysiology, clinical consequences, and medical therapy: Part I. Circulation. 2003; 108(12):1527-1532.

Dahm A, Osterud B, Hjeltnes N, Sandset PM, Iversen PO. Opposite circadian rhythms in melatonin and tissue factor pathway inhibitor type 1: does daylight affect coagulation?. J Thromb Haemost. 2006; 4(8):1840-1842.

Dunn EJ, Ariëns RA. Fibrinogen and fibrin clot structure in diabetes. Herz. 2004; 29(5):470-479.

ElGendy AA, Abbas AM. Effects of warfarin and L-carnitine on hemostatic function and oxidative stress in streptozotocin-induced diabetic rats. J Physiol Biochem. 2014; 70(2):535-546.

Eriksson M, Carlberg B, Eliasson M. The disparity in longterm survival after a first stroke in patients with and without diabetes persists: the Northern Sweden MONICA study. Cerebrovasc Dis. 2012; 34(2):153-160.

Favaro E, Miceli I, Bussolati B, Schmitt-Ney M, Cavallo Perin P, Camussi G, Zanone MM. Hyperglycemia induces apoptosis of human pancreatic islet endothelial cells: effects of pravastatin on the Akt survival pathway. Am J Pathol. 2008; 173(2):442-450.

Ferreiro JL, Angiolillo DJ. Diabetes and antiplatelet therapy in acute coronary syndrome. Circulation. 2011; 123(7):798813.

Ferreiro JL, Gómez-Hospital JA, Angiolillo DJ. Platelet abnormalities in diabetes mellitus. Diab Vasc Dis Res. 2010; 7(4):251-259.

Follenius M, Weibel L, Brandenberger G. Distinct modes of melatonin secretion in normal men. J Pineal Res. 1995; 18(3):135-140.

Ho FM, Liu SH, Liau CS, Huang PJ, Lin-Shiau SY. High glucose-induced apoptosis in human endothelial cells is 
mediated by sequential activations of c-Jun $\mathrm{NH}(2)$ terminal kinase and caspase-3. Circulation. 2000; 101(22):2618-2624.

Ido Y, Carling D, Ruderman N. Hyperglycemia-induced apoptosis in human umbilical vein endothelial cells: inhibition by the AMP-activated protein kinase activation. Diabetes. 2002; 51(1):159-167.

Jou MJ, Peng TI, Yu PZ, Jou SB, Reiter RJ, Chen JY, Wu HY, Chen CC, Hsu LF. Melatonin protects against common deletion of mitochondrial DNA-augmented mitochondrial oxidative stress and apoptosis. J Pineal Res. 2007; 43(4):389-403.

Kakouros N, Rade JJ, Kourliouros A, Resar JR. Platelet function in patients with diabetes mellitus: from a theoretical to a practical perspective. Int J Endocrinol. 2011; Article ID 742719:1-14. doi:10.1155/2011/742719.

Korish AA, Abdel Gader AGM, Alhaider AA. Camel milk ameliorates the coagulopathy in streptozotocin diabetic rat model. Int J Dairy Technol. 2015; 68(1):79-87.

Kostovski E, Dahm AE, Iversen N, Hjeltnes N, Osterud B, Sandset PM, Iversen PO. Melatonin stimulates release of tissue factor pathway inhibitor from the vascular endothelium. Blood Coagul Fibrinolysis. 2011; 22(4):254259.

Loomans CJ, de Koning EJ, Staal FJ, Rookmaaker MB, Verseyden C, de Boer HC, Verhaar MC, Braam B, Rabelink TJ, van Zonneveld AJ. Endothelial progenitor cell dysfunction: a novel concept in the pathogenesis of vascular complications of type 1 diabetes. Diabetes. 2004; 53(1):195-199.

Minneman KP, Wurtman RJ. The pharmacology of the pineal gland. Annu Rev Pharmacol Toxicol. 1976; 16:33-51.

Montagnana M, Salvagno GL, Lippi G. Circadian variation within hemostasis: an under recognized link between biology and disease?. Semin Thromb Hemost. 2009; 35(1):23-33.

Ohaeri OC, Adoga GI. Anticoagulant modulation of blood cells and platelet reactivity by garlic oil in experimental diabetes mellitus. Biosci Rep. 2006; 26(1):1-6.

Osende JI, Badimon JJ, Fuster V, Herson P, Rabito P, Vidhun R, Zaman A, Rodriguez OJ, Lev EI, Rauch U, Heflt G, Fallon JT, Crandall JP. Blood thrombogenicity in type 2 diabetes mellitus patients is associated with glycemic control. J Am Coll Cardiol. 2001; 38(5):1307-1312.

Pashalieva I, Decheva L, Stancheva E, Nyagolov Y, Negrev N. Melatonin and luzindole-induced effects on integral blood coagulation parameters in rats. Compt Rend Acad Bulg Sci. 2014; 67(9):1269-1274.

Pinotti M, Bertolucci C, Portaluppi F, Colognesi I, Frigato E, Foà A, Bernardi F. Daily and circadian rhythms of tissue factor pathway inhibitor and factor VII activity. Arterioscler Thromb Vasc Biol. 2005; 25(3):646-649.

Reiter RJ, Li K, Gonzalez-Brito A, Tannenbaum MG, Vaughan MK, Vaughan GM, Villanua MA. Elevated environmental temperature alters the responses of the reproductive and thyroid axes of female Syrian hamsters to afternoon melatonin injections. J Pineal Res. 1988; 5(3):301-315.

Rezzani R, Rodella LF, Bonomini F, Tengattini S, Bianchi $\mathbf{R}$, Reiter RJ. Beneficial effects of melatonin in protecting against cyclosporine A-induced cardiotoxicity are receptor mediated. J Pineal Res. 2006; 41(3):288-295.

Rodella LF, Favero G, Foglio E, Rossini C, Castrezzati S, Lonati C, Rezzani R. Vascular endothelial cells and dysfunctions: role of melatonin. Front Biosci (Elite Ed). 2013; 5:119-129.

Sanz G, Fuster V. Polypill and global cardiovascular health strategies. Semin Thorac Cardiovasc Surg. 2011; 23(1):2429.

Schäfer A, Fraccarollo D, Vogt C, Flierl U, Hemberger M, Tas P, Ertl G, Bauersachs J. Improved endothelial function and reduced platelet activation by chronic
HMG-CoA-reductase inhibition with rosuvastatin in rats with streptozotocin-induced diabetes mellitus. Biochem Pharmacol. 2007; 73(9):1367-1375.

Schalkwijk CG, Poland DC, van Dijk W, Kok A, Emeis JJ, Dräger AM, Doni A, van Hinsbergh VW, Stehouwer CD. Plasma concentration of $\mathrm{C}$-reactive protein is increased in type 1 diabetic patients without clinical macroangiopathy and correlates with markers of endothelial dysfunction: evidence for chronic inflammation. Diabetologia. 1999; 42(3):351-357.

Stancheva E, Zarkova A, Pashalieva I, Nyagolov Y, Negrev N. Melatonin inhibits the protein C anticoagulant pathway in rats. Scr Sci Med. 2015; 47(1):57-63.

Tai SH, Chen HY, Lee EJ, Chen TY, Lin HW, Hung YC, Huang SY, Chen YH, Lee WT, Wu TS. Melatonin inhibits postischemic matrix metalloproteinase-9 (MMP9) activation via dual modulation of plasminogen/plasmin system and endogenous MMP inhibitor in mice subjected to transient focal cerebral ischemia. J Pineal Res. 2010; 49(4):332-341.

Takada Y, Urano T, Watanabe I, Taminato A, Yoshimi T, Takada A. Changes in fibrinolytic parameters in male patients with type 2 (non-insulin-dependent) diabetes mellitus. Thromb Res. 1993; 71(5):405-415.

Tunali T, Sener G, Yarat A, Emekli N. Melatonin reduces oxidative damage to skin and normalizes blood coagulation in a rat model of thermal injury. Life Sci. 2005; 76(11):1259-1265.

Vaidyula VR, Boden G, Rao AK. Platelet and monocyte activation by hyperglycemia and hyperinsulinemia in healthy subjects. Platelets. 2006a; 17(8):577-585.

Vaidyula VR, Rao AK, Mozzoli M, Homko C, Cheung P, Boden G. Effects of hyperglycemia and hyperinsulinemia on circulating tissue factor procoagulant activity and platelet CD40 ligand. Diabetes. 2006b; 55(1):202-208.

Wilkinson IB, MacCallum H, Rooijmans DF, Murray GD, Cockcroft JR, McKnight JA, Webb DJ. Increased augmentation index and systolic stress in type 1 diabetes mellitus. QJM. 2000; 93(7):441-448.

Wirtz PH, Spillmann M, Bärtschi C, Ehlert U, von Känel R. Oral melatonin reduces blood coagulation activity: a placebo-controlled study in healthy young men. J Pineal Res. 2008; 44(2):127-133.

Yeom E, Byeon H, Lee SJ. Effect of diabetic duration on hemorheological properties and platelet aggregation in streptozotocin-induced diabetic rats. Sci Rep. 2016; 6:21913. doi: 10.1038/srep21913. 